\title{
UCI 法によるコンクリートの圧縮強度推定に関する基礎的研究 BASIC STUDY ON ESTIMATING STRENGTH OF CONCRETE BY UCI METHOD
}

\author{
稲 葉 洋平*, 市之瀬 敏勝**, 閑 田徹志*** \\ Yohei INABA, Toshikatsu ICHINOSE and Tetsushi KANDA
}

\begin{abstract}
In order to develop a non-destructive in-situ testing for strength of concrete, Ultrasonic Contact Impedance (UCI) method was modified and verified with experimental data. The conclusions are below.

1. Because the Young's modulus of concrete is changing with age, it is necessary to measure the Young's modulus of concrete at that age in order to estimate the strength of concrete by UCI method.

2. It is possible to estimate the young's modulus by UCI method, using steel plate of $0.2 \mathrm{~mm}$ thickness between material and Vickers diamond.

3. There is a high correlation between measured hardness and strength of concrete.

4. This modified UCI method has some possibility of being a micro-destructive in-situ testing for strength and Young's modulus of concrete.
\end{abstract}

Keywords : UCI method, Strength of concrete, Non-destructive testing, Young's modulus, In-situ testing UCI 法，コンクリート強度，非破壊試験，弾性係数，現場測定

\section{1. はじめに}

コンクリートの最も重要な物性の一つとして圧縮強度があり, 建 築物の施工においてはコンクリートの圧縮強度が設計基準強度を下 回ることがないように管理する必要がある。コンクリートは一般的 な工業製品とは異なり, 固まる前の半製品の状態で出荷され, 圧縮 強度の発現は養生条件に強く依存寸る材料であるため, 可能であれ ば硬化後に現場で構造物そのものの強度を確認することが望ましい。

しかし，一般的に行われる構造体コンクリートの圧縮試験は，新 築建物からコア採取をする必要があり，これは躯体を損ねることに つながるため, 好ましい試験方法とはいえない。そこで候補に挙が るのが非破壊試験であるが, 推定精度や適用できる強度範囲などを 考慮すると現状の非破壊試験では十分であるとは言えず, 新たな技 術の開発が望まれる。現状の非破壊試験である反発度法 ${ }^{1)}$, 超音波 法 2)や弾性衝撃波法 3)などは, 弾性係数と相関の高い物性を測定す ることで弾性係数を推定し，この弾性係数から圧縮強度を推定寸る 手法である。しかし, そもそも弾性係数と圧縮強度は異なる物性で あるため, 弾性係数から推定される圧縮強度の推定精度には限界が あると考えられる。また, 微破壊試験である引っかき傷法 4)や貫入 抵抗法 5)は高強度コンクリートへの適用が困難 6)である。

本研究では，金属材料の硬さを調べるために行われている UCI (Ultrasonic Contact Impedance） 法 7)8991 10) を応用し，コンクリー
卜の圧縮強度推定に用いる方法（以下, UCI 強度推定法）の開発を 行った。この方法は, 以下の特長を持つ。

(1)微破壞試験である

(2)現場で測定可能な試験である

(3)簡易に校正が可能である

(4)局所的な測定が可能である

本手法は，目に見えないほどではあるが破壊試験であり，弾性係 数から推定する非破壊試験に比べ, 推定精度の向上が望める。また, UCI 法がそもそも金属の硬さ試験に用いられていることから，高強 度コンクリートへの適用も十分に可能と考えられる。

本研究では, UCI 法により圧縮強度推定を行う際に解決寸べき問 題点を明らかにし，その適切な解決方法について理論的検討を行う。 その後, 実験的検討を行うことで UCI 強度推定法の妥当性を検証す るとともに,より精度を高めるための手法についても考察を加える。

\section{2. 試験法の概要}

\section{1 UCI 法}

ASTM A 103811)に規格される UCI 法は硬さ試験の一つであり， ビッカース硬さ試験を改良したものである。一般的なビッカース硬 さ試験(JIS Z224412))は，ピラミッド状のダイヤモンド圧子を材料表 面にある荷重で押し付け，生じた凹みの面積（以下，圧痕面積）を
* 鹿島技術研究所建築生産グループ 主任研究員·修士 (工学)

** 名古屋工業大学工学部建築デザイン工学科 教授・工博

*** 鹿島技術研究所建築生産グループ グループ長・Ph. D
Senior Research Engineer, Kajima Technical Research Institute of Technology, M. Eng.

Prof., Nagoya Institute of Technology, D. Eng.

General Manager, Kajima Technical Research Institute, Ph. D 
測定する試験である。圧子を押し付けた荷重を圧痕面積で除して, ビッカース硬さとするものであり，金属材料を対象に広く行われる 試験である。このビッカース硬さ試験は圧痕面積を顕微鏡で目視に より確認するため, 測定に時間がかかる, 観察者によって測定值が 異なる, といった問題点がある。この点を改良したものが UCI 法を 用いたビッカース硬さ試験（以下，単に UCI 法と呼ぶ）である。

UCI 法によれば, 従来は目視で行なっていた圧痕面積測定の作業 を電気的に処理できるようになる。そのため, ビッカース硬さ試験 の測定は瞬時に行われ，測定者によって測定値が異なるなどの問題 も生じなくなる。具体的には，以下のような処理が行われている。

$\mathrm{UCI}$ 試験機（写真 1 ）の圧子（プローブ先端）は, 図 1 (a)のよう に, ある周波数 $f$ で常時, 振動している。この圧子を測定する材料 (例えば鋼) の表面に一定の力で押し付けると, 図 1 (b)のように材 料にある面積 $A_{0}$ の圧痕が生じる。この圧痕を介して振動エネルギー の一部が逸散し, 振動数が減少する。測定材料の硬さが小さく, 圧 痕面積が大きいほど, 圧子は強く拘束されることになるため, 振動 数の変化量 $(\Delta f)$ が大きくなる。このように, 振動数の変化量と圧痕 面積とは一定の相関があることから, 圧痕面積を測定するかわりに 振動数の変化量を測定することで, 電気的に測定処理をしているの が UCI 法である。なお, 以下ではコンクリートの硬さ測定值から圧 縮強度を推定する手法について検討しているが, 実際の硬さの測定 はコンクリートのモルタル部分で行っているため, 正確にはコンク リートのモルタル部分の硬さから, コンクリートの圧縮強度を推定 する技術であることを予め断っておく。

\section{2 UCI 法の問題点}

このように従来のビッカース硬さ試験の問題点を改良したものが UCI 法であるが，コンクリートに適用するためには問題点がある。 以下，その問題点について説明する。

振動数の変化量は圧痕面積と一定の相関があることは先述したが, 振動数の変化量は測定材料の弾性係数によっても変化する。このた め, 測定材料の弾性係数が既知でなければ, 振動数の変化量から圧 痕面積を正確に推定することができない。金属材料であれば弾性係 数は不変であることが多く, 事前に測定しておけば問題となること はないが，今回の測定対象はコンクリートであり，弾性係数は材齢 や養生条件によって変化し，一定值ではない。このため, コンクリ ートをUCI 法で測定するためには, その時点におけるコンクリート の弾性係数も併せて把握する必要があり, その測定手法を開発する 必要がある。

\section{3 解決方法（UCI 法による弾性係数の測定）}

上述した UCI 法の問題点を解決するために, 弾性係数の測定手法 について検討する。なお, 当然のことであるが，弾性係数の測定手 法についても, 圧縮強度の推定技術と同様に以下の点が求められる。 (1)非破壞または微破壞試験であること, (2)現場で測定可能なこと, (3)簡易に校正が可能なこと。

新たな弾性係数の測定手法であるが,これについても UCI 法を応 用することで対応した。UCI 法を応用して弾性係数を測定すること の主な利点は, 以下の 2 つである。

1 ）UCI 強度推定法にとって適切な弾性係数が得られる

2 ）他の試験機を準備する必要がない

UCI 法で測定されたビッカース硬さを修正するための弾性係数

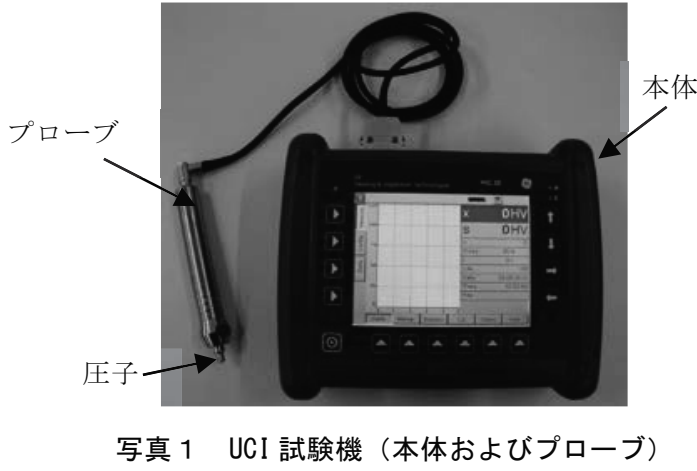

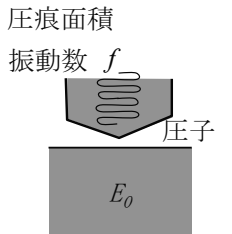

(a)押し付け前

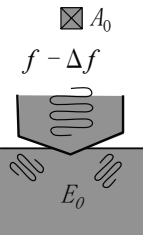

(b)鋼のみ

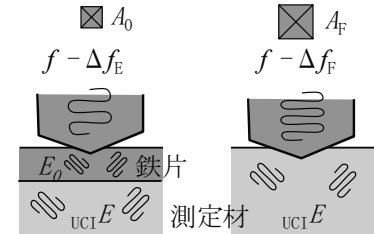

（c)鉄片+測定材 （d)測定材のみ

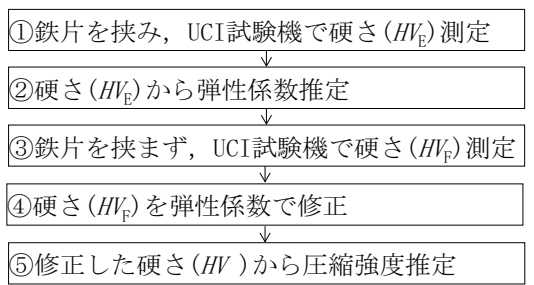

(e)強度測定のフロー

図 1 UCI 強度推定法の全体フロー

としては，同じ UCI 法により推定される弾性係数(以下, $\mathrm{UCI} E$ ), 寸 なわち UCI 試験機が認識している弾性係数が原理的に最も適切で あり，必ずしも JIS A 1149 で定められる弾性係数(以下，JIS $E$ )が適 切なわけではない。なお，通常は校正を行うため，UCI 試験機が認 識する弾性係数と JIS A 1149 で定められる弾性係数は概ね一致さ せることができる。

以下, UCI 法による弾性係数の測定原理について説明する。圧子 の振動数の変化 $(\Delta f)$ が, 測定材料の圧痕面積 $(A)$ および弾性係数 $(E)$ に依存していることは既に述べた。すなわち，(1)式が成立している 11)。

$$
\Delta f=f(A, E)
$$

測定の際には, $A$ も $E$ も不明であるため, 測定の結果として $\Delta f$ が得られても， $A$ も $E$ も不定である。しかし，ここで $A$ を一定值 $A_{0}$ に固定することができたとすれば，測定值である $\Delta f$ から $E$ を推 定することが可能となる。すなわち，圧痕面積が一定になるように した上で UCI 法による測定をした場合，その測定值である $\Delta f$ は材 料の弾性係数 $E$ と一定の相関を持つため, $E$ を推定できる。このこ とから, 弾性係数をUCI 法により測定するためには, 圧痕面積が一 定になる方法を検討すればよい。

\section{4 具体的な解決手段}

圧痕面積を一定にする方法であるが，図 1 (c)のように，圧子と測 定材料の間に薄い鉄片を挟む方法が考えられる 10)。圧子が直接触れ るのは鉄片であり，一定規格の鉄片を使用寸れば品質が安定してい ることから，押し付ける荷重が一定の場合には圧痕面積も一定とな 
る。鉄片が十分に薄い場合（ただし, 圧子により鉄片下のコンクリ 一トに圧痕が生じない程度の厚みは必要), 振動数の変化量は鉄片下 の材料の弾性係数を反映するため, 振動数の変化量から材料の弾性 係数を把握することが可能となる。ただし，コンクリート表面には 空隙があり，この上で鉄片を挟んだ測定をすると異常值が検出され るため, この場合はデータを棄却する必要がある。以上が, UCI 法 により弾性係数を把握する原理の概要である。

なお，文献 10)との主な相違は, 以下の 3 つである。(1)測定対象 が塑性材料（金属および樹脂）ではなく，コンクリートという脆性 材料であること, (2)推定された弾性係数を硬さ指標の修正に用いる こと，(3)間に挟むのは測定材料表面よりも軟らかい金属片でなけれ ばならないとされているが, 本研究では測定材料であるコンクリー トよりも硬い鉄片を挟んでいること。

\section{5 校正曲線}

非破壊や微破壊試験が間接的であるのに対し，破壊試験は直接的 であることから，圧縮強度は破壊試験の結果を真值とすることが多 い。そのため, 非破壊・微破壊試験は校正曲線を使用寸るなど可能 な範囲で高精度の試験法とすべきであり, UCI 法も校正曲線を用い て精度を高めることが可能な試験方法の一つである。これは以下に 示すように, 反発度法に比べ, 校正曲線の作成が簡便なことによる。

反発度法は測定時の反発エネルギーが高いため, 測定のためには 測定箇所が十分に拘束されている必要がある。これは, 拘束されて いる場合と拘束されていない場合とで，測定值が異なってしまうか らである。そのため, 例えば小さい供試体などでコンクリート調合 ごとに校正曲線を作成するといった簡便な手法を用いることができ ない。一方, UCI 強度推定法は測定箇所に与えるエネルギーが小さ いため，校正曲線を作成するための供試体は小さくてよく，拘束を する必要もない。このため, 調合ごとに校正曲線を作成し, より高 い精度を確保することが可能である。ただし, 反発度法に比べて局 所的な測定になるため, 測定数をさらに多くする必要がある。

\section{6 測定および評価手順の概要}

これまでの検討をまとめると, UCI 強度推定法は, 図 1 (e) に示 すように以下の測定および評価を行うことで, コンクリートの圧縮 強度推定が可能と考えられる。なお, 精度向上のためには予めテス トピースにより圧縮強度および弾性係数との校正曲線を得ておくこ とが望ましい。UCI 法の測定結果は, 鉄片を挟んで測定した結果と 鉄片を挟まないで測定した結果があるため，ここではそれらを区別 するために前者を $H V_{\mathrm{E}}$ ，後者を $H V_{\mathrm{F}}$ と表記する。

(1)鉄片を挟んで，UCI 試駼機によりビッカース硬さ $\left(H V_{\mathrm{E}}\right)$ を測定 (2)弾性係数の校正曲線より, $H V_{\mathrm{E}}$ から測定材料の弾性係数を推定 (3)図 1 (d)のように, 鉄片を挟まずに, UCI 試験機によりビッカース 硬さ $\left(H V_{\mathrm{F}}\right)$ を測定

(4)測定材料の弾性係数を用いて $H V_{\mathrm{F}}$ を修正した $H V$ を計算 (5)圧縮強度の校正曲線より, $H V$ から測定材料の圧縮強度を推定

\section{3. 予備実験}

\section{1 予備実験概要}

2.6 で示した手法により, 圧縮強度の推定可能性を確認する前に, 予備実験として弾性係数の推定可能性をコンクリート以外の単一材 料により確認する。UCI 強度推定法成立の有無は, 弾性係数の推定

\section{表 1 記号の意味一覧}

\begin{tabular}{|c|c|}
\hline 記号 & 意味 \\
\hline E & 弾性係数 \\
\hline $\mathrm{JIS} E$ & JIS A 1149 で得られる弾性係数 \\
\hline${ }_{\mathrm{UCI}} E$ & UCI法で推定される弾性係数 \\
\hline$F_{c}$ & 圧縮強度 \\
\hline $\mathrm{JIS} F_{c}$ & JIS A 1108で得られる圧縮強度 \\
\hline $\mathrm{UCI}_{\mathrm{CI}} F_{c}$ & UCI法で推定される圧縮強度 \\
\hline$\Delta f$ & 振動数変化量 \\
\hline$\Delta f_{\mathrm{E}}$ & 鉄片を挟んで測定した際の振動数変化量 \\
\hline$\Delta f_{\mathrm{F}}$ & 鉄片を挟まないで測定した際の振動数変化量 \\
\hline$H V$ & UCI試験機で測定され，実際の弾性係数を考慮したビッカース硬さ \\
\hline$H V_{\mathrm{E}}$ & UCI試験機で鉄片を挟んで測定した際の測定値 \\
\hline$H V_{\mathrm{F}}$ & UCI試験機で鉄片を挟まないで測定した際の測定值 \\
\hline
\end{tabular}

が可能であるとする点に依存しており，まずはこの妥当性を示す。 なお，コンクリート以外の材料により確認する理由は主に $2 つ$ つ る。1つは, 複合材料であるコンクリートは, 本質的に弾性係数の 測定可能性を判断する材料としては適していないこと。もう 1 つは, 後に示すようにコンクリートの弾性係数は $10 \sim 40 \mathrm{GPa}$ 程度と範囲 が狭く，妥当性の検証には不十分と考えたためである。

\section{2 測定材料}

測定する材料は, 鋼 $(210 \mathrm{GPa})$, アルミニウム $(70 \mathrm{GPa})$, 鉛(16GPa), エポキシ樹脂 $(2 \mathrm{GPa})$ の 4 種類とする。ここで，（）内の数字は弾性 係数を示している。これらの材料は比較的容易に入手が可能であり, それぞれの弾性係数が大きく異なることから, UCI 強度推定法によ る弾性係数の推定可能性検討に適している。なお，引張試験(JIS K7161)を行ったエポキシ樹脂以外の弾性係数の值については試験 を実施しておらず，文献 13)によっている。そのため，弾性係数の 值は数 $\mathrm{GPa}$ 程度の誤差がある可能性がある。

\section{3 試験方法}

UCI 法の試験は，G 社の UCI 試験機を使用し，センサー部分で あるプローブは周波数 $70 \mathrm{kHz}$ ，測定時の作用荷重が $50 \mathrm{~N}$ のものを 用いている。

測定回数は, 各材料について, 鉄片を挟んだ状態で 30 回とし, 平均值により評価した。鉄片は厚さ 0.2 および $0.3 \mathrm{~mm}$ を用い, サ イズは測定時に扱いや寸い幅 $8 \mathrm{~mm}$, 長さ $90 \mathrm{~mm}$ の鋼材を使用した。 鉄片の厚さであるが，厚すぎる場合は鉄片下の測定材料の弾性係 数変化に鈍感になり, 精度が低くなる。また，薄すぎる場合は，鉄 片下の測定材料にまで圧痕が生じてしまい，弾性係数の影響だけで なく測定材料の硬さの影響を含んだ測定值となり, 精度が低くなる。 0.04 $0.6 \mathrm{~mm}$ の異なる厚さの鉄片 9 種類を試した結果, $0.2 \mathrm{~mm}$ 厚 さ未満では圧痕が鉄片裏側（測定材料と接していた面）からでも確 認できたため, 薄すぎると判断した。 $0.2 \mathrm{~mm}$ 以上で最も薄い厚さが 妥当と考え, 鉄片の厚さ $0.2 \mathrm{~mm}$ を標準としている。

\section{4 単一材料の弾性係数の推定（校正曲線）}

弾性係数の校正曲線を検討するために, UCI 試験機が使用してい る内部計算式を示しておく。以下の(2)，(3)式が内部計算の基本式で ある。ただし，鋼材を想定している。(2)式は弾性理論から求まる理 論式 78)であり，(3)式は硬さの定義式 12)である。なお, ASTM A 1038 にもあるように，UCI 法は文献 7)〜10)を基礎にして開発されてお り，原則的には(2)式は寸べての UCI 試験機で成立すると考えらえ る。なお，UCI 試験機は $H V$ の測定值のみを表示する仕様になって おり, 振動数の変化 $(\Delta f)$ そのものは表示されないことを断っておく。 
以下, 式中の記号で下添字に 0 がつくものは定数である。また, 今 後使用する記号の一部についてその意味を表 1 にまとめる。

$$
\begin{aligned}
& \Delta f=\alpha_{0} E_{0} \sqrt{A} \\
& H V=\beta_{0} \frac{F_{0}}{A} \\
& \alpha_{0}, \beta_{0}: \text { 係数 (定数), } \Delta f: \text { 振動数の変化量 } \\
& E_{0}: \text { 鋼の弾性係数, } A: \text { 圧痕面積 } \\
& H V: \text { ビッカース硬さ, } F_{0}: \text { 作用荷重(定数) }
\end{aligned}
$$

(2)，(3)式から未知数 $A$ を消去して(4)式が得られる。本式が, UCI 試験機が振動数変化からビッカース硬さを計算している式である。 なお， $\beta_{0}$ はビッカース硬さの定義から定まる定数であるため, 鉄片 を挟んでも変化しないが, $\alpha_{0}$ は鉄片を挟むことなどにより変化する。

$$
H V=\alpha_{0}^{2} \beta_{0} \frac{F_{0} E_{0}^{2}}{\Delta f^{2}}
$$

鉄片を挟んで測定した場合, 鉄片により圧痕面積が $A_{0}$ の一定值に なり， $\alpha_{0}$ が $\alpha_{0}^{\prime}$ になるとすると，(2)式に代わり(5)式となる。

$$
\Delta f_{\mathrm{E}}=\alpha^{\prime}{ }_{0} E \sqrt{A_{0}}
$$

$\mathrm{UCI}$ 試験機は，鉄片の有無に関わらず(4)式により $\Delta f$ から $H V$ を 計算しているため, (4)式に(5)式を代入することで, 鉄片を挟んだ場 合の測定值 $\left(H V_{E}\right)$ は以下となる。なお, $E$ を $\mathrm{UCI} E, \Delta f$ を $\Delta f_{\mathrm{E}}$ に置き 換え, $\gamma_{0}=\alpha_{0} E_{0} / \alpha^{\prime}{ }_{0} \sqrt{\beta_{0} F_{0} / A_{0}}$ とする。

$$
\begin{aligned}
& H V_{\mathrm{E}}=\alpha_{0}{ }^{2} \beta_{0} \frac{F_{0} E_{0}{ }^{2}}{\Delta f_{\mathrm{E}}{ }^{2}}=\alpha_{0}{ }^{2} \beta_{0} \frac{F_{0} E_{0}{ }^{2}}{\alpha_{0}^{\prime}{ }^{2} \mathrm{UCI}^{2} A_{0}} \\
& \therefore \mathrm{UCI} E=\frac{\alpha_{0} E_{0}}{\alpha_{0}^{\prime}} \sqrt{\frac{\beta_{0} F_{0}}{A_{0}}} \frac{1}{\sqrt{H V_{\mathrm{E}}}}=\gamma_{0} \frac{1}{\sqrt{H V_{\mathrm{E}}}}
\end{aligned}
$$

すなわち, UCI $E$ と $1 / \sqrt{H V_{\mathrm{E}}}$ とは $\gamma_{0}$ を係数とした比例関係にある。

\section{5 測定結果}

弾性係数と UCI 法の測定で得られた $1 / \sqrt{H V_{\mathrm{E}}}$ との相関を図 2 に示 す。なお, $H V_{\mathrm{E}}$ の変動係数は鉛, アルミニウム, 鋼が $5 \%$ 程度, エ ポキシが $10 \%$ 程度であった。これより，(7)式とは異なり, 測定值の 平方根の逆数と弾性係数とは比例せず, 原点も通らない。なお, 図 2 中の凡例にある $0.2 \mathrm{~mm}$ および $0.3 \mathrm{~mm}$ は挟んだ鉄片厚さを示す。

この原因として, $H V_{\mathrm{E}}$ と $\mathrm{UCI} E$ の 2 つの 0 点のシフトが考えられ る。 $H V_{\mathrm{E}}$ の測定值は試験機本来の使用法で得られたものではないた め，そのままでは絶対評価はできず，相対評価しかできない。これ は, $H V の 0$ 点調節が硬さに対してなされており, 弾性係数に対し てなされているわけではないからである。そのため, $H V_{\mathrm{E}}$ の測定值 を絶対值として意味ある測定值とするには 0 点調節を行う必要があ る。この調節が $H V_{\mathrm{E}}$ の 0 点のシフトである。一方, 鉄片を挟むと測 定值は変化するため, 鉄片を挟まない場合の $\mathrm{UCI} E$ の推定式では誤差 が生じ, 補正が必要となる。これが $\mathrm{UCI} E$ の 0 点のシフトである。こ れらを考慮した式を(8)式に示す。

$$
\mathrm{UCI} E=\gamma_{0} \frac{1}{\sqrt{H V_{\mathrm{E}}-\varepsilon_{0}}}-\delta_{0}
$$

鉄片の厚さが $0.2 \mathrm{~mm}$ の場合は $\varepsilon_{0}=557 \mathrm{HV}, 0.3 \mathrm{~mm}$ の場合は $\varepsilon_{0}$ $=501 \mathrm{HV}$ とした場合の $H V_{\mathrm{E}}$ と弾性係数との相関を図 3 に示す。図 3 より, 0 点のシフトを考慮した $H V_{\mathrm{E}}$ の平方根の逆数と弾性係数とは $210 \mathrm{GPa}$ までの範囲にわたって理論通りに比例関係にある。それぞ

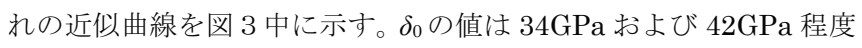
となる。

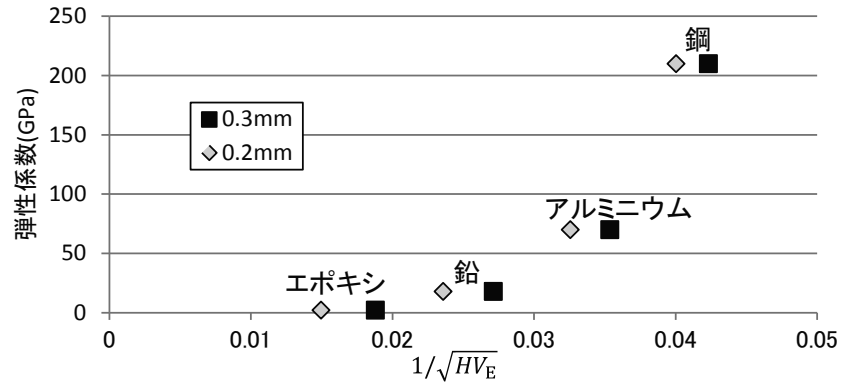

図 $2 H V_{\mathrm{E}}$ と弾性係数の相関

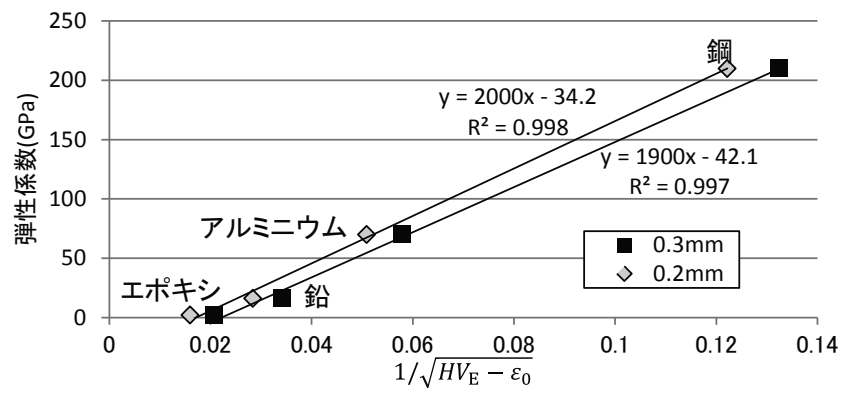

図 3 シフトを考慮した $H V_{\mathrm{E}}$ と弾性係数の相関

以上から， $H V_{\mathrm{E}}$ の測定值はシフトを考慮することで弾性係数と理 論通りの相関を示すこと， $\varepsilon_{0}$ および $\delta_{0}$ の值は間に挟む材料によって 変化すること, $\varepsilon_{0}$ および $\delta_{0}$ の值は複数の材料を測定することにより 同定可能であることが示された。また，これらの帰結として，UCI 試験機による弾性係数の推定が可能であることが示された。

単一材料については, 図 3 に示すように間に挟む材料ごとに定ま る 1 つの校正曲線 $\left(0.2 \mathrm{~mm}\right.$ の鉄片を挟む場合は $\gamma_{0}=2000, \delta_{0}=34 \mathrm{GPa}$, $\varepsilon_{0}=557 \mathrm{HV}$ ，の校正曲線）により，種類の異なる材料の弾性係数で あっても推定できる可能性が高い。ただし，この校正曲線は複合材 料であるコンクリートにはそのままでは適用できない。コンクリー トの場合, モルタル部分の測定值から弾性係数を推定することにし ているが，このように推定された弾性係数はあくまでモルタルの弾 性係数であり, コンクリートの弾性係数とは異なる。一般にコンク リートの弾性係数は, 骨材種類や骨材量により変化し，モルタルだ けより大きな值となる。よって, コンクリートなどの複合材料は, 使用材料ごとに $\gamma_{0}, \varepsilon_{0}, \delta_{0}$ を補正した校正曲線により推定する必要が ある。

\section{4. 実験}

\section{1 実験概要}

2.6 で示した手法により, コンクリートの圧縮強度・弾性係数の 推定が実際に可能であるかどうかを確認するために，圧縮試験およ び UCI 測定を行い, それらの相関を把握した。実験要因と水準を表 2 に示す。実験要因は水セメント比(W/C)および養生条件の 2 つと し, 水セメント比は 3 水準 $(45,55,65 \%)$, 養生条件は 2 水準 (封縅, 気中）とした。

ここで封緘養生とは，打設後に乾燥しないよう試験体を密封し， 温度 $20^{\circ} \mathrm{C}$ において養生したものであり, 実験時においても可能な範 囲でビニール袋により密封状態とした。気中養生とは, 打設後 1 日 まで封縅養生するが, その後脱型し, 温度 $20^{\circ} \mathrm{C} ・$ 相対湿度 $60 \%$ の 
恒温恒湿槽で養生したものである。

圧縮試験および UCI 測定は 6 材齢時（1，3，7，14，28，56 日）に おいてそれぞれ行っている。なお，材齢 1 日は気中養生も封縅養生 も養生が同じであるため, 封縅養生の測定のみ行っている。試験体 は $\phi 100 \times 200 \mathrm{~mm}$ のサミットモールドを用い, 各調合・材齢・養生 について 1 本ずつ, 計 36 本の試験体を作製した。試験体側面のモ ルタル部分をUCI 試験機で測定後, 同試験体の圧縮試験を行い, 圧 縮強度および弾性係数を測定した。

\section{2 使用材料および調合}

使用材料を一覧にして表 3 , 調合表を一覧にして表 4 に示す。

\section{3 試験方法}

試験機は，3.3 で使用したものと同じである。測定回数は, 試験 体 1 本について, 鉄片を挟んだ状態で 30 回, 挟まない状態で 30 回 の計 60 回とし，それぞれの平均值で評価した。鉄片は厚さ $0.2 \mathrm{~mm}$ を用い, 測定位置は, 円柱試験体側面の中央付近としている。圧縮 試験および弾性係数試験は JIS A 1108 および JIS A 1149 に準じて 行なっている。

\section{4 硬さの評価式について}

UCI 法の試験機は自動計算により振動数の変化を硬さに変換し て表示するが，この自動計算された硬さは弾性係数をある定数と仮 定して計算しているため, 実際の弾性係数を考慮した適切な指標之 なっていない。そのため, 自動計算された硬さを適切な指標の硬さ に修正する必要がある。以下，修正方法を示す。

(4)式より, UCI 試験機内部で自動計算された硬さ $\left(H V_{\mathrm{F}}\right)$ は, 鋼材 の弾性係数 $E_{0}$ を用いると,以下のように計算されていたことになる。 なお， $\Delta f$ を $\Delta f_{\mathrm{F}}$ に置き換えている。

$$
H V_{\mathrm{F}}=\alpha_{0}^{2} \beta_{0} \frac{F_{0} E_{0}^{2}}{\Delta f_{\mathrm{F}}^{2}}
$$

すなわち, 自動計算された硬さ $\left(H V_{\mathrm{F}}\right)$ を弾性係数の変動を考慮し た適切な硬さ $(H V)$ 変換するためには, 以下の式が示すように, $H V_{\mathrm{F}}$ の值に $E^{2} / E_{0}^{2}$ を乗ずればよい。

$$
H V=\alpha_{0}{ }^{2} \beta_{0} \frac{F_{0} E^{2}}{\Delta f_{\mathrm{F}}{ }^{2}}=\alpha_{0}{ }^{2} \beta_{0} \frac{F_{0} E_{0}{ }^{2}}{\Delta f_{\mathrm{F}}{ }^{2}} \times \frac{E^{2}}{{E_{0}}^{2}}=H V_{\mathrm{F}} \times \frac{E^{2}}{{E_{0}}^{2}}
$$

\section{5 測定結果}

$H V_{\mathrm{E}}$ の経時変化を図 4 に示す。また, $\mathrm{W} / \mathrm{C}=55 \%$ の封縅について, 標準偏差をエラーバーで示す。各水準における変動係数の平均は 13\%程度である。 $H V$ E は経時とともに減少傾向にあり，HVE は圧縮 強度や弾性係数が大きくなると小さくなる傾向にある。また, 気中 養生は封緘養生に比べて $H V_{\mathrm{E}}$ が大きい。

$H V_{\mathrm{F}}$ の経時変化を図 5 に示寸。また, $\mathrm{W} / \mathrm{C}=55 \%$ の封緘について, 標準偏差をエラーバーで示す。各水準における変動係数の平均は $19 \%$ 程度である。 $H V_{\mathrm{F}}$ の值は, 経時とともに若干増加傾向にあるが, 材齢 7 日以降は大きく変化しない。また, 気中養生は封縅養生に比 べ $H V_{\mathrm{F}}$ が大きい。

弾性係数の経時変化を図 6 に, 圧縮強度の経時変化を図 7 に示寸。 封緘に比べ, 気中は弾性係数および圧縮強度が小さく, 乾燥により 強度発現を妨げられていることが分かる。

以上から, $H V_{\mathrm{E}}$ と $H V_{\mathrm{F}}$ はコンクリートの圧縮強度や弾性係数と 相関があり, 圧縮強度や弾性係数が増加すると $H V_{\mathrm{E}}$ は減少するが, $H V_{\mathrm{F}}$ は大きく変化しない傾向にある。また, 気中養生は封縅養生に

\begin{tabular}{|c|c|c|c|c|c|c|c|}
\hline \multirow{2}{*}{ 実験要因 } & $\mathrm{W} / \mathrm{C}(\%)$ & \multicolumn{2}{|c|}{45} & \multicolumn{2}{|c|}{55} & \multicolumn{2}{|c|}{65} \\
\hline & 養生 & 封縅 & 気中 & 封縅 & 気中 & 封縅 & 気中 \\
\hline \multicolumn{8}{|c|}{ 表 3 使用材料一覧 } \\
\hline 材料 & 水 & \multicolumn{2}{|c|}{ セメント } & \multicolumn{2}{|c|}{$\begin{array}{l}\text { 細骨材 } \\
\end{array}$} & \multicolumn{2}{|c|}{ 粗骨材 } \\
\hline 種類等 & 調布市 & \multicolumn{2}{|c|}{$\begin{array}{c}\text { 普通ポルトランド } \\
\text { セメント }\end{array}$} & \multicolumn{2}{|c|}{$\begin{array}{c}\text { 八王子産砕砂 } \\
\text { 成田山砂 }\end{array}$} & \multicolumn{2}{|c|}{$\begin{array}{l}八 \text { 王子・秩父 } \\
\text { 青梅産砕砂 }\end{array}$} \\
\hline
\end{tabular}

表 2 実験要因と水準

\section{表 4 調合一覧}

\begin{tabular}{c|c|c|c|c|c|c|c}
\hline \multirow{2}{*}{ NO. } & \multirow{2}{*}{ 記号 } & \multirow{2}{*}{$\begin{array}{c}\text { W/C } \\
\text { (\%) }\end{array}$} & $\begin{array}{c}\text { 細骨材率 } \\
(\%)\end{array}$ & \multicolumn{4}{|c}{ 単位質量 $\left(\mathrm{kg} / \mathrm{m}^{3}\right)$} \\
\cline { 5 - 8 } & & & & 水 & セxン卜 & 細骨材 & 粗骨材 \\
\hline \hline 1 & 45 & 45.0 & 45.7 & 175 & 389 & 780 & 960 \\
\hline 2 & 55 & 55.0 & 48.7 & 175 & 319 & 861 & 936 \\
\hline 3 & 65 & 65.0 & 49.8 & 184 & 284 & 881 & 920 \\
\hline
\end{tabular}

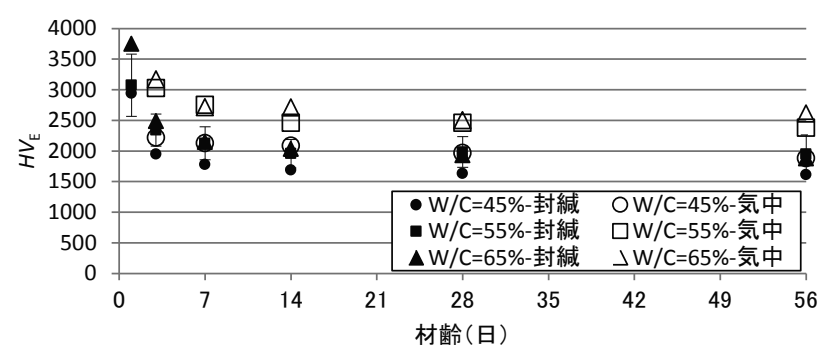

図 $4 H V_{E}$ の経時変化

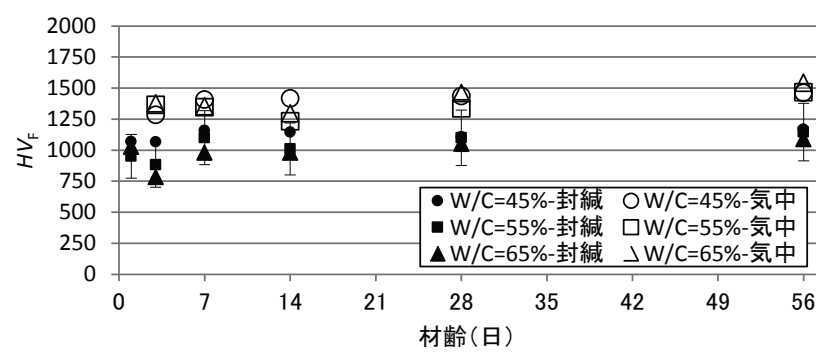

図 $5 \quad H V_{F}$ の経時変化

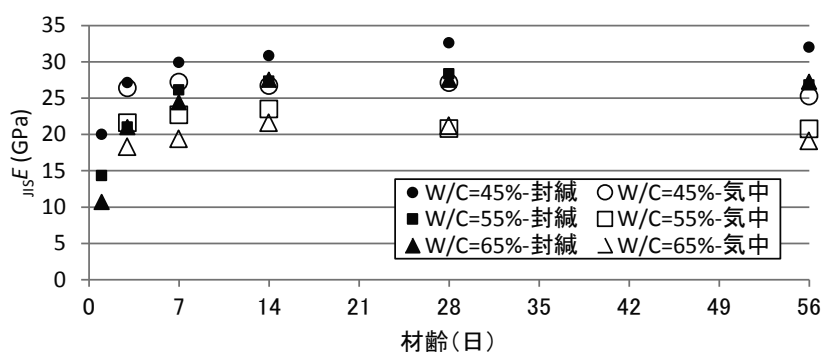

図 6 弾性係数 ${ }_{\mathrm{JI}} E$ の経時変化

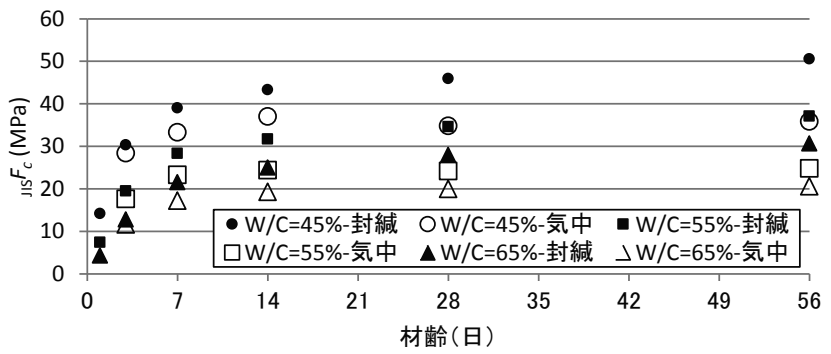

図 7 圧縮強度 ${ }_{\mathrm{JI}} F_{c}$ の経時変化 
比べ， $H V_{\mathrm{E}}, H V_{\mathrm{F}}$ ともに大きくなる傾向にある。

4.6 弾性係数の推定（校正曲線）

測定值が得られたので, 弾性係数を推定するための校正曲線を求 める。弾性係数を推定するための基本式は(8)式である。 $\mathrm{UCI} E$ と $1 / \sqrt{H V_{\mathrm{E}}-\varepsilon_{0}}$ とは $\gamma_{0}$ を係数とした比例関係にあり, $H V_{\mathrm{E}}$ は弾性係数 が大きくなると小さくなる傾向にあることが説明できる。圧縮試験 で得られた弾性係数 JIS $E$ と UCI 法の測定で得られた $1 / \sqrt{H V_{\mathrm{E}}-\varepsilon_{0}}$ と の相関を図 8 (養生の影響) および図 9 (W/C の影響) に示す。な お， $0.2 \mathrm{~mm}$ の鉄片を使用して測定しているため, $\varepsilon_{0}=557 \mathrm{HV}$ として 計算している。 3.5 に示したように, コンクリートの場合の $\varepsilon_{0}$ の值 はモルタルとは異なる可能性がある。 $\varepsilon_{0}$ の同定には広範な弾性係数 測定が必要となるが, 今回測定した弾性係数の範囲内では $\varepsilon_{0}=557 \mathrm{HV}$ としても図 8 から線形性を確認することができるため, 誤差は少ないと判断し,この值を用いている。線形性がない場合は, 弾性係数の推定誤差が大きくなるため， $\varepsilon_{0}$ の值を修正するべきであ る。参考までに最小二乗法による線形近似式と決定係数 $\mathrm{R}^{2}$ の值を図 中に示した。計算式通りに比例関倸(封緘: $\gamma_{0} \fallingdotseq 1580$, 気中: $\left.\gamma_{0} \fallingdotseq 1080\right)$ にある。なお，その決定係数は封縅(0.950)の方が気中 $(0.663)$ よりも 大きいが，データの範囲が気中 $(18 〜 27 \mathrm{GPa})$ と封縅(11〜33GPa)で 異なるため，単純に良否を比較することはできない。

\section{7 圧縮強度の推定（校正曲線）}

$H V$ は金属材料では硬さの指標であるが，(3)式が示すようにコン クリートの強度 $\left(F_{c}\right)$ と同じ次元(荷重/面積)を持ち, ともに破壊荷重 をその面積で除した強度指標であることから $H V$ と $F_{c}$ は高い相関を 持つと考えられる。これから $H V$ と $F_{c}$ が線形関係にあるものと寸れ ば，(10)式と併せて以下の関係式（ $k_{0}$ は傾き， $\theta_{0}$ は $\mathrm{y}$ 切片を示寸も のとする) が成立する。 4.4 で示したように $H V_{\mathrm{F}} に E^{2 /} E_{0}^{2}$ を乗ず れば $H V$ に変換できる。

$$
F_{c}=k_{0} \times H V+\theta_{0}=k_{0} \times \frac{\mathrm{UCI}^{2}}{E_{0}{ }^{2}} \times H V_{\mathrm{F}}+\theta_{0}
$$

なお, $H V$ を具体的に計算するためには, $E_{0}$ を定める必要がある。 $E_{0}$ の正確な值は, 試験機の内部設定值であり不明であるが，今回の 測定は鋼材を対象とした設定で行われているため, $E_{0}$ は鋼材の標準 值である $210 \mathrm{GPa}$ として $H V$ を算出した。

圧縮試験で得られた圧縮強度 JIS $F_{c}$ と UCI 強度推定法で得られた $H V$ との相関を図 10 (養生の影響), 図 11 (W/C の影響) に示 す。コンクリートのビッカース硬さ $(H$ Hは $5 \sim 30$ 程度であり, 既往 の測定結果 ${ }^{14115)}$ と比較しても概称妥当な範囲と考えられる。参考ま でに最小二乗法による線形近似式と決定係数 $\mathrm{R}^{2}$ の值を図 10 中に 示した。計算式通りに比例関係(封縅: $k_{0} \fallingdotseq 1.70, \theta_{0} \fallingdotseq+0.368 \mathrm{MPa}$, 気 中: $\left.k_{0} \fallingdotseq 1.70, \theta_{0} \fallingdotseq-3.20 \mathrm{MPa}\right)$ にあり, その決定係数は封縅が 0.967 , 気中が 0.818 である。 $\theta_{0}$ の值は試験機の校正が正しくなされていれ ば，0 となるべきであり，概衫妥当と考えられる。図 11 から，水 セメント比の違いに関わらず，すべてのデータが概ね同一の直線上 にあり, 水セメント比の違いが与える影響は小さいと考えられる。

\subsection{UCI 強度推定法による強度推定式}

まとめると, コンクリートの圧縮強度 $\mathrm{UCI}_{c} F_{c}$ の推定式は, UCI 試 験機の測定值 $\left(H V_{\mathrm{E}}, H V_{\mathrm{F}}\right)$, 校正のための実験で定まる係数 $\left(k_{0}, \gamma_{0}, \delta_{0}\right.$, $\left.\varepsilon_{0}, \theta_{0}\right)$ および $E_{0}(=210 \mathrm{GPa})$ を用いると $(8) ，(11)$ 式より以下となる。

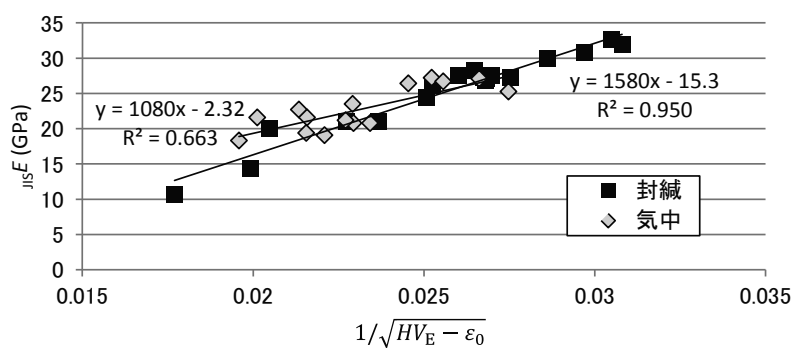

図 8 弾性係数 ${ }_{\mathrm{JI}} E$ と $H V_{\mathrm{E}}$ の相関（養生の影響）
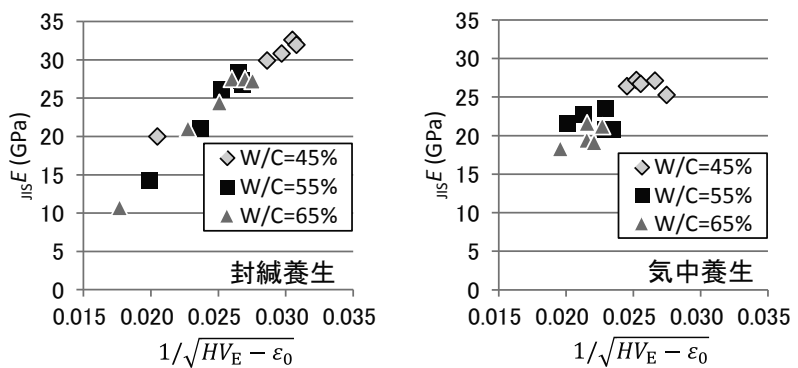

図 9 弾性係数 $\mathrm{JI} E$ と $H V_{E}$ の相関 (W/C の影響)

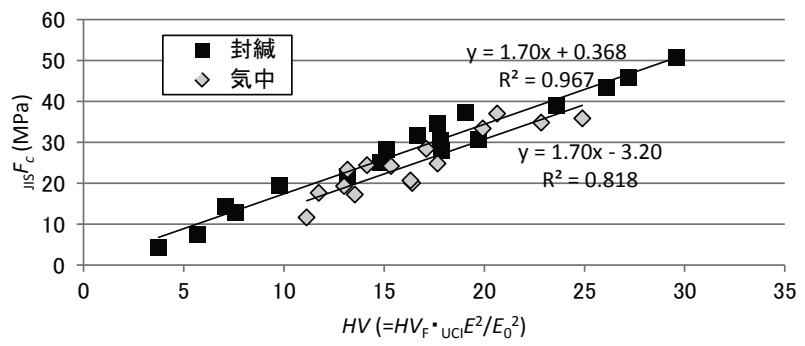

図 10 圧縮強度 ${ }_{\mathrm{JI}} F_{c}$ と $H V$ の相関（養生の影響）
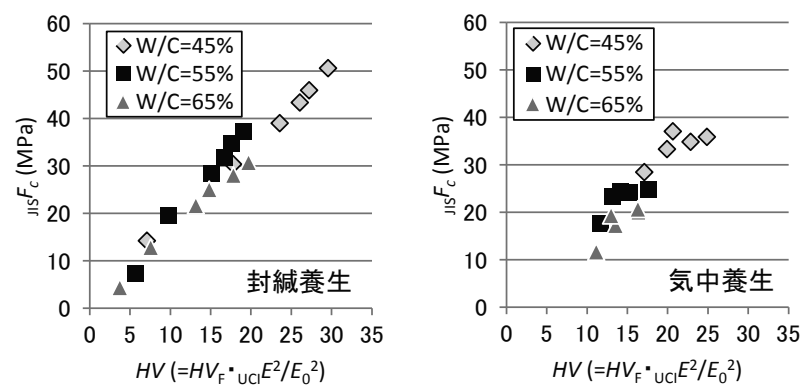

図 11 圧縮強度 JIS $F_{c}$ と $H V$ の相関（W/C の影響）

$$
\mathrm{UCI} F C=\frac{k_{0}}{E_{0}{ }^{2}} \times H V_{\mathrm{F}} \cdot\left(\gamma_{0} \frac{1}{\sqrt{H V_{\mathrm{E}}-\varepsilon_{0}}}-\delta_{0}\right)^{2}+\theta_{0}
$$

以上の結果から, UCI 強度推定法がコンクリートの弾性係数およ び圧縮強度を高い精度で推定できる手法となりえる可能性を示せた ものと考えている。

\section{5. 考察}

\section{1 養生条件による影響}

養生条件による影響について，以下の傾向がみられる。

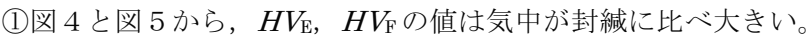
(2)図 8 と図 10 から, 養生により校正曲線が異なる可能性がある。 (1)は，主に試験体の含水状態による影響と考えられる。気中養生 
は封緘養生に比べ含水率が低下する。UCI 強度推定法は, 圧子の振 動数変化から硬さの推定を行う手法である。そのため, 含水率が小 さいと水分子による振動阻害が減少し, 振動数変化 $(\Delta f)$ が小さくな る。(4)式より, $\Delta f$ の減少は $H V$ の増加をもたらすため, 封縅養生 に比べ, 気中養生の方が $H V_{\mathrm{E}}, H V_{\mathrm{F}}$ は大きくなったと考えられる。

(2)関しては, 以下のことが考えられる。前述したように含水状 態により $H V_{\mathrm{E}}, H V_{\mathrm{F}}$ は変化する。含水状態により, 実際のコンクリ 一トの弾性係数や圧縮強度が $H V_{\mathrm{E}}, H V_{\mathrm{F}}$ と同じ程度に変化するなら ば，養生条件に関わらず校正曲線は同一となるため，校正曲線にお いて含水状態を考慮する必要はない。しかし，同一の校正曲線とな らない場合は, 強度や弾性係数の推定に含水状態の考慮が必要とな る可能性が生じる。現時点ではデータが少ないため, 今後は, これ らの含水率の影響についてさらに検討していきたい。

以上より, UCI 強度推定法において校正曲線を得るために準備す る試験体の養生方法は, 実際の測定対象の養生条件と同じとするの が望ましいと考えられる。

\section{2 水セメント比 $(\mathrm{W} / \mathrm{C})$ による影響}

水セメント比 $(\mathrm{W} / \mathrm{C})$ による影響について考察を加える。図 9 およ び図 11 より, 水セメント比の違いが校正曲線に与える影響はほと んどみられない。校正曲線を得るために準備する試験体の調合は, 骨材やセメント種類などの材料が同じであれば, 水セメント比が 1 種類だけであっても特に問題はない可能性がある。

\section{6. まとめ}

微破壞によるコンクリートの圧縮強度推定手法として, UCI 法を 用いた新しい評価手法の理論的背景を考察し, 実験によりこれを検 証した結果, 以下の結論が得られた。

1. UCI 法を応用して, コンクリートの強度推定を行うためには, 測定時点における弾性係数を把握する必要があることを示した。

2. 測定時点における弾性係数を把握するためには, UCI 試験機で 測定する際に，鉄片などを挟むことで可能となることを示した。

3. 実験により検証した結果, 単一材料の弾性係数については, $210 \mathrm{GPa}$ 程度までの範囲において理論通りの関係性が得られ, 鉄 片などを挟むことにより UCI 試験機で推定可能であることを示 した。

4. 実験により検証した結果, UCI 強度推定法により得られた結果 は, 圧縮試験により得られた圧縮強度および弾性係数と高い相関 が得られた。

5. UCI 強度推定法はコンクリートの弾性係数および圧縮強度を高 い精度で推定できる手法となりえる可能性がある。

6. UCI 強度推定法において校正曲線を得るために準備する試験体 の養生方法は, 実際の測定対象の養生条件と同じとするのが望ま しいと考えられる。

7. 校正曲線を得るために準備する試験体の調合は, 材料が同じで あれば，水セメント比が 1 種類だけであっても特に問題はない可 能性がある。

\section{参考文献}

1）日本工業規格 JIS A 1155，コンクリートの反発度の測定方法，2013

2) ASTM C 597-71, Standard Test Method for Pulse Velocity Through
Concrete, pp.361-364, 1971

3) ASTM C 1383-98, Standard Test Method for Measuring the P-Wave Speed and the Thickness of Concrete Plate Using the Impact-Echo Method, American Society for Testing and Materials, 1998

4）湯浅昇，笠井芳夫ほか 2 名：引っかき傷によるコンクリートの圧縮強度 試験方法の提案，日本非破壊検査協会，シンポジウム「コンクリート構 造物の非破壊検査への期待」論文集, Vol.1, pp.115-122, 2003.8

5）三浦尚，岩城一郎，板橋洋房：針貫入試験によるコンクリート構造物の 劣化診断に関する研究，土木学会論文集，No.620，V-43，pp.245-255， 1999.5

6）谷川恭雄監修：コンクリート構造物の非破壊検査・診断方法，株式会社 セメントジャーナル, p.36, 2004.9

7) C. Kleesattel and G.M.L. Gladwell: The Contact - Impedance Meter 1, ULTRASONICS, Vol.6, pp.175 -180, 1968.7

8) G.M.L. Gladwell and C. Kleesattel: The Contact - Impedance Meter 2, ULTRASONICS, Vol.6, pp.244 -251, 1968.10

9) C. Kleesattel and G.M.L. Gladwell: The Contact - Impedance Meter 3, ULTRASONICS, Vol.7, pp.57-62, 1969.1

10) C. Kleesattel: Contact Impedance Meter. Part IV, ULTRASONICS, Vol.8, pp.39-48, 1970.1

11) ASTM A 1038-05, Standard Practice for Portable Hardness Testing by the Ultrasonic Contact Impedance Method, 2005

12) JIS Z 2244，ビッカース硬さ試験一試験方法, 2009

13）国立天文台編：理科年表 平成 22 年, 丸善株式会社, p.379, 2009.11

14）藤井卓 : 複合セメント硬化体の微小硬度特性について, 第 47 回セメント 技術大会講演集,pp.398-403,1993

15）大脇英司：ビッカース硬さを用いたコンクリート構造物の劣化診断，検 查技術, pp.24-27, 2000.4 


\title{
BASIC STUDY ON ESTIMATING STRENGTH OF CONCRETE BY UCI METHOD
}

\author{
Yohei INABA*, Toshikatsu ICHINOSE ${ }^{* *}$ and Tetsushi KANDA *** \\ * Senior Research Engineer, Kajima Technical Research Institute of Technology, M. Eng. \\ *** Prof., Nagoya Institute of Technology, D. Eng. \\ *** General Manager, Kajima Technical Research Institute, Ph. D
}

Concrete is the most important material to construct structures. One of the most important properties of concrete is a compressive strength which is needed to control over the specified design standard strength after hardening. The compressive strength test is very important but generally tested objects are test pieces which molded cylinder, not structural concrete itself. The compressive strength of concrete is influenced by curing, the strength of test piece is different from that of structural concrete. The strength test is desirable to be tested in-situ.

One of the most popular strength tests for structural concrete is compressive strength test with boring core sampling. But this test is destructive, so the structure is damaged. Then desirable test is non-destructive. But the existing non-destructive tests have some problems about accuracy, strength range, etc.

It is necessary to investigate new strength test which has following 4 properties. 1) micro destructive, 2) testing in-situ, 3) easiness of calibrating, 4) capability of measuring the local area. The UCI (Ultrasonic Contact Impedance) method has these 4 properties, so basic study about UCI applying to concrete has developed.

UCI method has developed for metal materials in 1960's to measure Vickers hardness automatically by electric device. UCI method is micro destructive, more accurate and applicable for high strength concrete with portable electric device. But UCI method has not be applied to concrete for many years, because of changing Young's modulus with time. The UCI method needs Young's modulus for estimating Vickers hardness, so Young's modulus needs to be measured at the same time. But there is no method to measure Young's modulus at the same time.

Improving the UCI method to estimate Young's modulus and compressive strength is investigated and verified. The conclusions are below.

1. Because the young's modulus of concrete is changing with age, it is necessary to measure the Young's modulus of concrete at that age in order to estimate the strength of concrete by UCI method.

2. It is possible to estimate the young's modulus by UCI method, using steel plate of $0.2 \mathrm{~mm}$ thickness between material and Vickers diamond.

3. There is a high correlation between measured hardness and strength of concrete.

4. This modified UCI method has some possibility of being the micro-destructive in-situ testing for strength and Young's modulus of concrete. 